\title{
Glenoid Dimensions Affect Occurrence of Bankart Lesions in Patients with First Time Traumatic Anterior Shoulder Dislocations
}

\author{
Glenoid Boyutları, Ilk Kez Travmatik Öne Omuz Çıkığı Bulunan Hastalarda \\ Bankart Lezyonlarının Oluşumunu Etkiler
}

\author{
Mesut TAHTA $\odot$, Cetin ISIK $\odot$, Neryal TAHTA $\odot$, Muhittin SENER $\odot$
}

Ethics Committee Approval: This study approved by the Katip Celebi University Ethic Committee for Clinical Studies (19 May 2017, 2017/073).

Conflict of interest: The authors declare that they have no conflict of interest. Funding: None.

Informed Consent: Was taken from all participants.
Cite as: Tahta M, Isik C, Tahta N, Sener M. Glenoid Dimensions Affect Occurrence of Bankart Lesions in Patients with First Time Traumatic Anterior Shoulder Dislocations. Medeniyet Med J. 2019;34:117-22.

\begin{abstract}
Objective: The relationship between glenoid bone morphology and Bankart lesions has not been well elucidated. The relationship between the dimensions of glenoid bone and occurrence of labral tears in patients with first episode of traumatic dislocations was investigated in this study. Methods: In this retrospective cohort study, 226 patients who experienced first episode of glenohumeral dislocations and also met required criteria were evaluated. Patients were divided into two groups as those with (Group 1, $n=113$ ) and without a Bankart lesion (Group 2, $n=113$ ). Standard shoulder MRI sequences were obtained for all patients. Two-dimensional glenoid measurements were made and accordingly the longest superior to inferior (SI) length, the greatest anterior and posterior width (AP), and the most anteroposterior width at a point $2 / 3$ of the glenoid length (DD). Also, ratios between lengths and widths (SI/AP, SI/DD, AP/DD) were calculated. The groups were compared in terms of the glenoid dimensions and between dimensions. Results: There was no difference between groups in terms of age $(p=0.109)$, gender $(p=0.086)$, $A P(p=0.086)$ and $D D$ widths $(p=0.881)$, AP/DD ratio $(p=0.764)$. The mean SI value of the patients in Group 1 was significantly higher than Group $2(p=0.024)$. The mean SI/AP and SI/ $D D$ ratios of patients in Group 1 was significantly higher than Group $2(p<0.001$ and $p=0.039$, respectively).

Conclusions: The results of this study show a relationship between glenoid dimensions and occurrence of Bankart lesions. An increase in the SI length, SI/AP, and SI/DD ratios is related to an increase incidence in the occurrence of Bankart lesions.
\end{abstract}

Keywords: Dimension, dislocation, glenoid, morphology, shoulder

öz

Amaç: Glenoid kemik morfolojisi ile Bankart lezyonları arasındaki ilișki iyi aydınlatılmamıștır. Bu çalışmada ilk kez travmatik çıkıkları olan hastalarda glenoid boyutları ile labral yırtık oluşumu arasındaki ilişki incelenmiştir.

Yöntem: Bu retrospektif kohort çalışmasında, ilk kez glenohumeral dislokasyonu olan ve kriterleri karşılayan 226 hasta değerlendirildi. Hastalar iki gruba ayrıldı: Bankart lezyonu olanlar (Grup 1, $n=113$ ) ve olmayanlar (Grup 2, $n=113$ ). Tüm hastalar için standart omuz MRG sekansları alındı. Buna göre iki boyutlu glenoid ölçümleri yapıldı: en uzun superior-inferior (SI) uzunluk, ön-arka genișlik $(A P)$, glenoid uzunluğunun $2 / 3$ seviyesindeki en uzun ön-arka genișlik $(D D)$ ölçüldü. Ayrıca uzunluk ve genişlik oranları (SI/AP, SI/DD, AP/DD) hesaplandı. Gruplar, glenoid boyutları ve boyut oranları açısından karşılaştırıldı.

Bulgular: Gruplar arasında yaş $(p=0.109)$, cinsiyet $(p=0.086), A P(p=0.086)$ ve $D D$ genişlikleri $(p=0.881), A P / D D$ oranı $(p=0.764)$ açısından fark yoktu. Grup 1 'deki hastaların SI ortalama değeri Grup 2'den anlamlı olarak yüksekti $(p=0.024)$. Grup 1'deki hastaların ortalama SI/AP ve SI/DD oranları Grup 2'den anlamlı olarak yüksekti (sırasıyla, $p<0.001$ ve $p=0.039$ ).

Sonuc: Bu çalıșmanın bulguları, glenoid boyutları ile Bankart lezyonlarının ortaya çıkıșı arasında bir ilişki olduğunu göstermektedir. SI uzunluğunda, SI/AP ve SI/DD oranlarındaki artış, Bankart lezyonlarının oluşumu ile ilişskilidir.

Anahtar kelimeler: Bankart, boyut, çıkık, glenoid, morfoloji, omuz
Received: 18.03 .2019

Accepted: 08.05.2019

Online First: 10.06 .2019

Corresponding Author: M. Tahta

ORCID: 0000-0001-9660-1350 Katip Celebi University, Ataturk Training and Research Hospital, Department of Orthopaedics and Traumatology, Karabaglar, Izmir, Turkey mesuttahta@gmail.com

\section{Isik}

ORCID: 0000-0002-5128-1602 Emsey Hospital, Department of Orthopaedics and Traumatology, Istanbul, Turkey

N. Tahta

ORCID: 0000-0001-6939-1570 Dr Behcet Uz Children's Hospital, Department of Pediatric Hematology-Oncology, Izmir, Turkey

M. Sener ORCID: 0000-0002-4544-3644 Katip Celebi University, Ataturk Training and Research Hospital, Department of Orthopaedics and Traumatology, Izmir, Turkey 


\section{INTRODUCTION}

Traumatic anterior shoulder dislocation is one of the most common injuries among shoulder injuries with an incidence of $1.7 \%$ in the general population ${ }^{1}$ with Bankart lesions concomitantly occurring in $60-90 \%$ of these patients ${ }^{2,3}$.

The stability of the glenohumeral joint is provided by the complex relationship of anatomic structures acting statically and/or dynamically ${ }^{4}$. Static stabilizators include the geometry of the articulating surfaces, glenohumeral ligaments, negative intraarticular pressure and labrum ${ }^{5}$. Additionally, the stability of shoulder joint is proportional to the effective glenoid depth and morphology ${ }^{6}$ and such morphology may vary widely in the population ${ }^{7}$. In this context, it has been shown that patients with flatter glenoids have an increased risk of instability after a first episode of dislocation ${ }^{4}$ and there are several studies showing that glenoid morphology affects risk of recurrent dislocations ${ }^{4,8}$. However, the relationship between glenoid morphology and Bankart lesions is not well known.

In this study, we suggest that there is a possible association between the dimensions of glenoid and occurrence of labral tears in patients with first-time traumatic dislocations. To the best of our knowledge, there is no study in the literature evaluating the effect of glenoid dimensions or dimension ratios on occurrence of Bankart lesions. Thus, this study aims to assess such relationship in patients with first-time traumatic anterior shoulder dislocation, which could be considered as a predisposing factor in clinical practice.

\section{MATERIALS and METHODS}

This study approved by the Katip.Celebi University Ethic Cpmmittee for Clinical Studies (19 May 2017, 2017/073. Informed consent was taken from all participants.

In this retrospective cohort study, the magnetic resonance imaging (MRI) scans of patients with first-time traumatic anterior shoulder dislocations were evaluated, along with treatment rendered and follow-up between January 2011 and January 2017.

Patients between 18 and 65 years old who had been diagnosed with one acute traumatic anterior glenohumeral joint dislocation requiring manual reduction (first-time dislocators), and those with available magnetic resonance images were included in the study. Patients were excluded (a) if they had additional shoulder lesions(such as rotator cuff tear, glenoid or humerus fractures, SLAP lesion, biceps rupture, bony Bankart lesion)(b) inflammatory diseases, (c) posterior dislocation / multidirectional instability and (d) history of previous shoulder surgery. Patients who met the criteria were examined in two groups: as those with (Group 1), and without a Bankart lesion (Group 2).

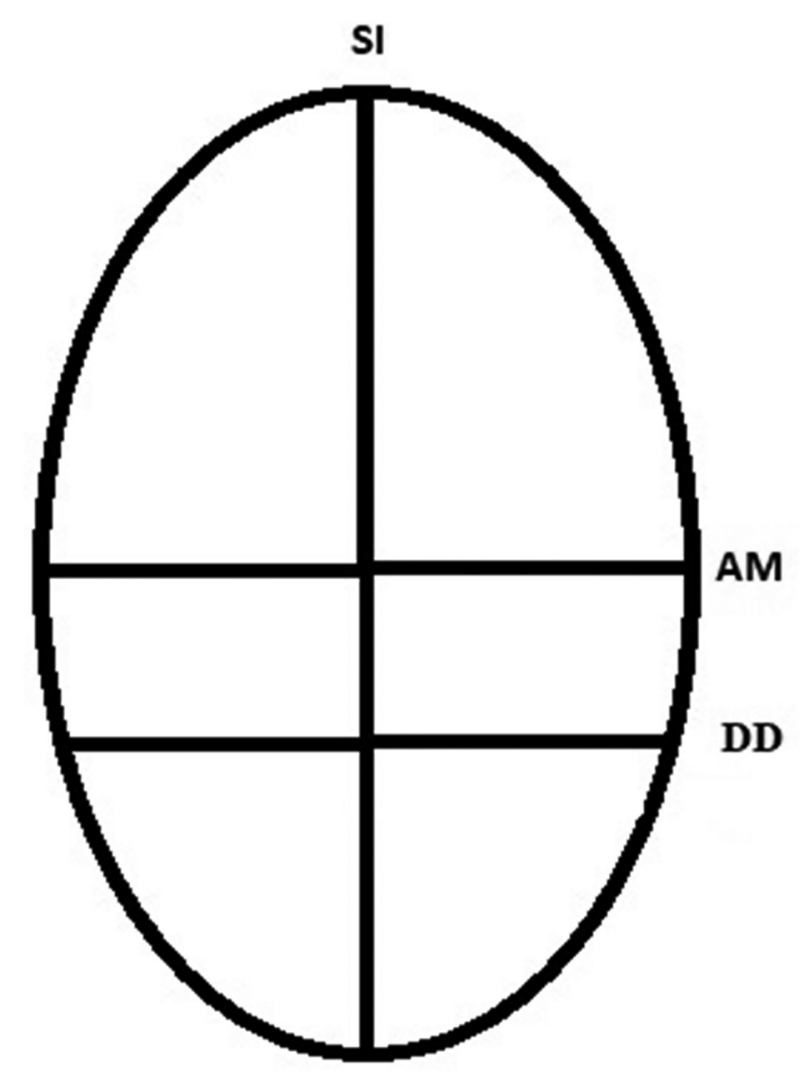

Figure 1. Schematic drawing of glenoid dimension measurements. 


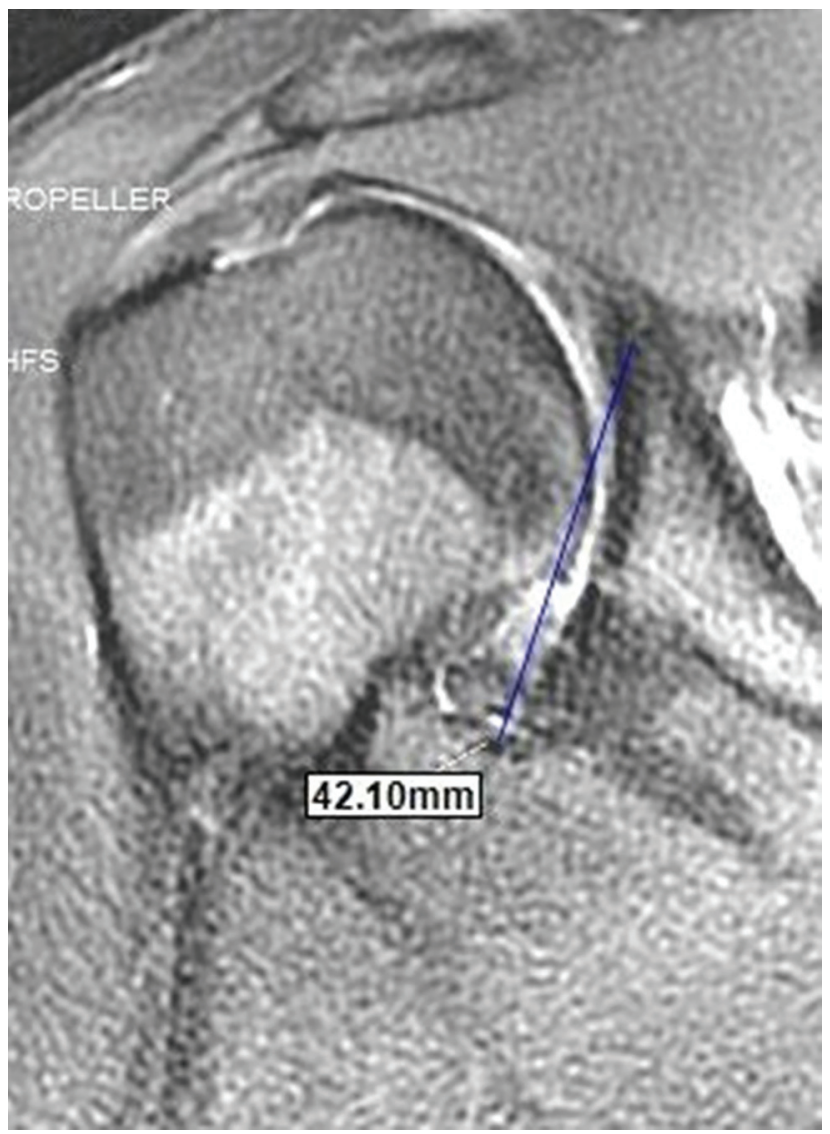

Figure 2. Measurement of superior-inferior (SI) dimension of glenoid on coronal MR image.

A statistical power analysis was performed for sample size estimation. The required power and size of the sample were calculated using the G-Power program (G-Power, Ver. 3.0.10, Universitat Kiel, Germany). With a Type 1 error of 0.05, and a Type 2 error of 0.05 , and a difference of f 50.22 and power of 0.90 , and a total number of 113 patients were needed to meet this effect size. In accordance with the power analysis, 113 MR images were evaluated in each group. All the MRI scans taken were assessed by two authors separately, using computer- based by Probel PACS Viewer (Probel Software, Izmir, Turkey) program. The mean value of two measurements was used for such variables.

Standard shoulder MRI sequences were obtained for all patients on a 1,5 Tesla scanner. Also, fast-spin echo (FSE) T1-weighted coronal, axial and sagittal images were obtained in all patients.

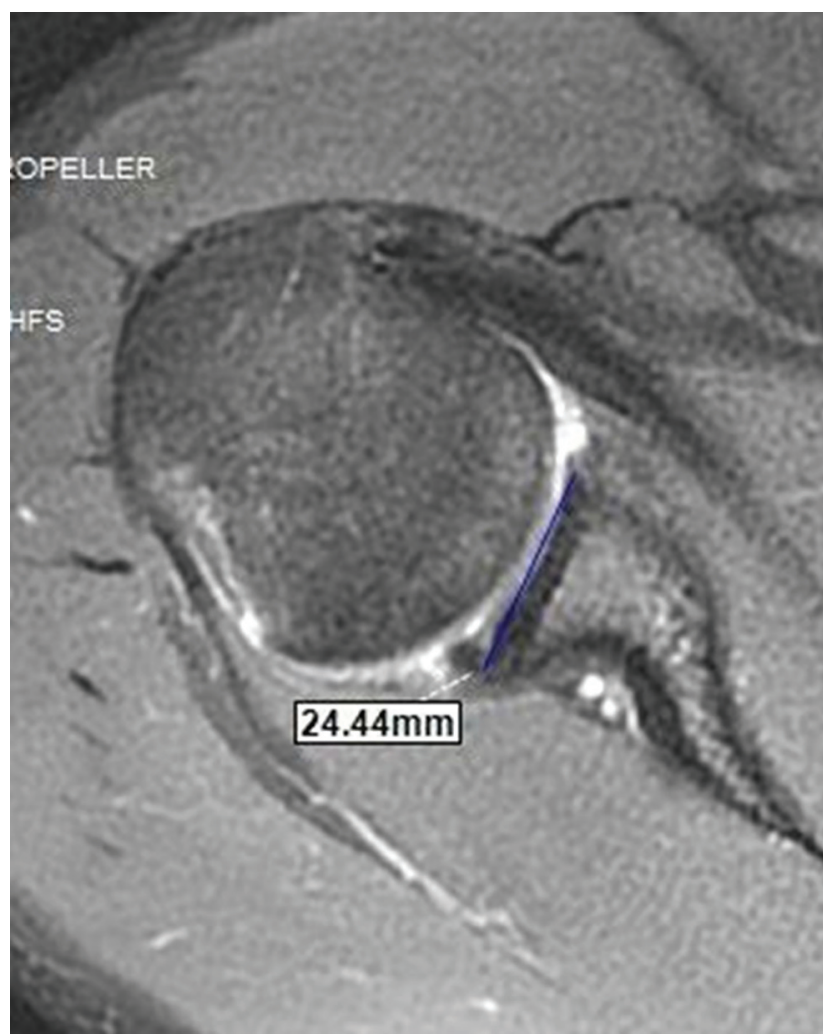

Figure 3. Measurement anterior-posterior (AP) dimension of glenoid on axial MR image.

Two-dimensional glenoid widths of each patient were measured (Figure 1). On the coronal view the most superior and inferior points of the contour of the subchondral bone of the glenoid were selected and the height (SI) was measured (Figure 2 ). On the axial view the most anterior and posterior points of the contour of the subchondral bone of the glenoid, perpendicular to the SI line were selected and the width (AP) was measured (Figure 3). Sagittal and axial views were combined, and the most anterior and posterior points of the contour of the subchondral bone of the glenoid, perpendicular to the SI line at distal $2 / 3$ of the glenoid(DD) was measured (Figure 4). Osteophytes were not included in the measurements, if present. SI/AP, SI/DD, AP/DD dimension ratios were calculated.

The groups were then compared in terms of the glenoid dimensions (SI, AP and DD) and dimension ratios of glenoid (SI/AP, SI/DD, AP/DD). 
The data were evaluated by a professional statistician using the SPSS 21.0 package program (SPSS, Inc., Chicago, IL, 139 USA). The Chi-square test was used for categorical variables and Student's $t$ test was used for non-categorical variables during statistical analysis. Descriptive statistics are given as mean \pm standard deviation. The Type-I error level was taken as $\alpha=0.05$.

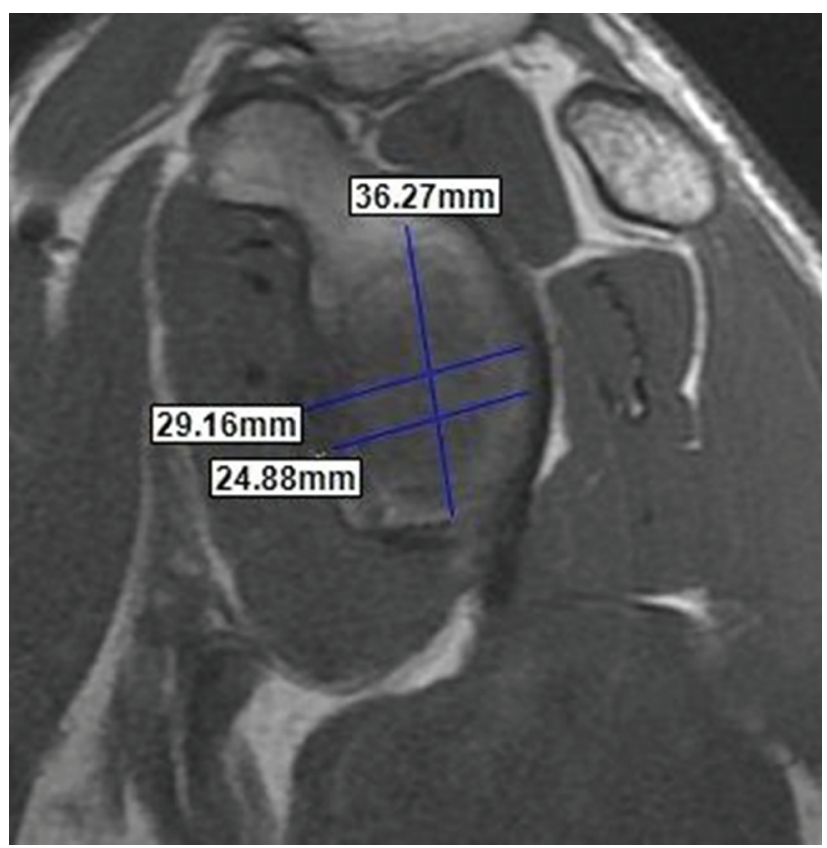

Figure 4. Measurement of distal 2/3 anterior-posterior (DD) dimension of glenoid on sagittal MR image.

\section{RESULTS}

Mean age of the patients in Group 1 was $37.8 \pm 12.8$ and $38.3 \pm 13.7$ in Group 2. There were 92 males (81.4\%),21 (18.6\%) females in Group 1 and 94 males (83.1\%), 19 (16.9\%) females in Group 2.There was no difference between groups in terms of age and gender $(p=0.109, p=0.086$, respectively) (Table 1 ).

Table 1. Comparison of groups in terms of demographic properties.

\begin{tabular}{lll}
\hline & Age & Gender $(\mathbf{M} / \mathbf{F})$ \\
\hline Group 1 & $37.8 \pm 12.8$ & $92 / 21$ \\
Group 2 & $38.3 \pm 13.7$ & $94 / 19$ \\
p & 0.109 & 0.086 \\
\hline
\end{tabular}

M: Male, F: Female
Evaluation of glenoid dimensions: The mean SI value of the patients in Group 1 was $34.1 \pm 5.4$ $\mathrm{mm}$ and $33.4 \pm 5.1 \mathrm{~mm}$ in Group 2 with a significant intergroup difference $(p=0.024)$. There was no significant difference between groups in terms of AP and DD values $(p=0.086$ and $p=0.881$, respectively) (Table 2 ).

Table 2. Comparison of groups in terms of mean glenoid dimensions and ratios.

\begin{tabular}{cllllll}
\hline SI & AP & DD & SI/AP & SI/DD & AP/DD \\
\hline Group 1 & $34.1 \pm 5.4$ & $24.6 \pm 4.8$ & $22.7 \pm 4.1$ & $1.4 \pm 0.2$ & $1.5 \pm 0.4$ & $1.0 \pm 0.1$ \\
Group 2 & $33.4 \pm 5.1$ & $24.9 \pm 4.7$ & $22.4 \pm 4.2$ & $1.3 \pm 0.3$ & $1.4 \pm 0.3$ & $1.0 \pm 0.2$ \\
0.024 & 0.086 & 0.881 & $<0.001$ & 0.039 & 0.764 \\
\hline
\end{tabular}

SI: Superior-Inferior, AP: Anterior-Posterior, DD: AnteriorPosterior width at 2/3 distal level of glenoid

Evaluation of glenoid dimension ratios: The mean SI/AP ratio of patients in Group 1 was $1.4 \pm 0.2$ and $1.3 \pm 0.3$ in Group 2 with a significant intergroup difference $(p<0.001)$. The mean SI/DD ratio of patients in Group 1 was $1.5 \pm 0.4$ and $1.4 \pm 0.3$ in Group 2 with a significant intergroup difference. $(p=0.039)$. There was no significant difference between groups in terms of AP/DD ratio $(p=0.764)$ (Table 2$)$.

\section{DISCUSSION}

In the current study, the relationship between occurrence of a Bankart lesion and glenoid dimensions/dimension ratios was evaluated. According to findings of the study, it was observed that the incidence of Bankart lesions increased as the increase in glenoid superoinferior diameter and ratios between superoinferior/anteroposterior diameters at first- time traumatic anterior shoulder dislocations (Figure 5).

Bigliani et al. $^{2}$ found that a significant capsular stretching occurs before failure when isolated boneinferior glenohumeral ligament-bone preparations are stretched. Such stretching would be accompanied by additional injuries, such as detachment of capsulolabral complex 9 , impression fracture of 


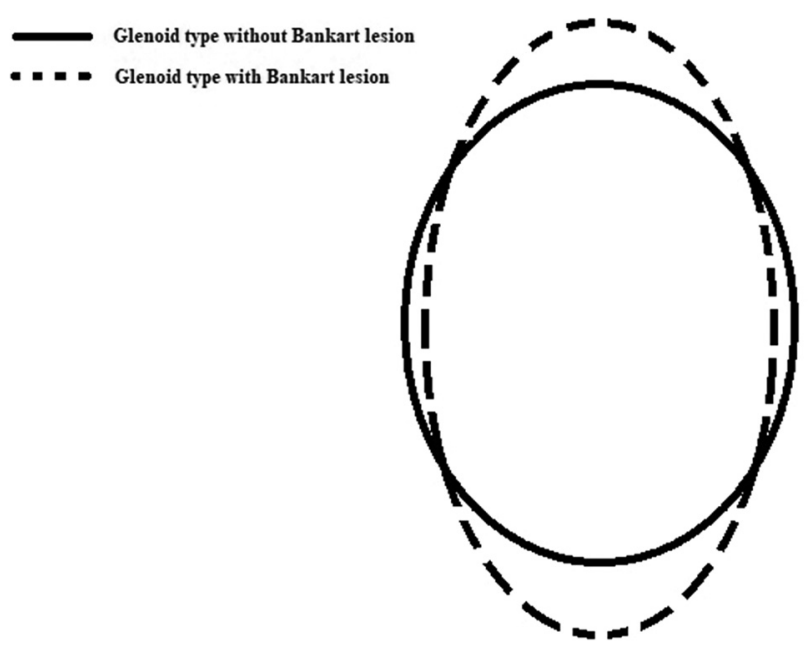

Figure 5. Schematic drawing of glenoid types with and without Bankart Lesion.

posterolateral humeral head ${ }^{10,11}$ and injury to the subscapularis tendon ${ }^{12,13}$ as a result of increase in the energy causing shoulder dislocation. In this context, $73 \%$ of patients with traumatic first-time anterior shoulder dislocations were reported to be accompanied by Bankart lesion ${ }^{14}$. Baker et al. ${ }^{15}$ reported the presence of a capsulolabral total dissection in $62 \%$ of their study participants based on intraoperative findings. Despite similar findings in the literature, it is still unclear in which patients a Bankart lesion may occur. It is reported that one of the predisposing factor is age $\mathrm{e}^{2,16,17}$. Another parameter that could be considered as a risk factor is male gender and it has already been reported among the predisposing factors of Hill-Sachs lesions ${ }^{18}$. In the current study, there was no difference between the two groups in terms of age and gender.

Bankart et al. ${ }^{9}$ reported that the capsulolabral complex is detached from the glenoid bone during the anterior shoulder dislocation and discussed that such separation occurred from the glenoid anterior margin. In our study, the glenoid detachment, which was detected by MRI, was evaluated. Bigliani et al. $^{2}$ recognized that in the clinical situation of an anterior dislocation, the ligament undergoes a strain injury and may become permanently stretched, with or without failed glenoid insertion. They also reported three sites of failed ligament insertion in respective percentages glenoid insertion (40\%), ligament substance $(35 \%)$ and humeral insertion (25\%). Speer et al. ${ }^{19}$ similarly reported that Bankart lesion was also associated with additional capsular damage. Based on this data, it could be deduced that the loading forces spread over all soft tissues, during shoulder dislocation. According to the data in this study, there is an association between the incidence of Bankart lesions and glenoid morphology more closely resembling an ellipsoid. The loading forces acting on the capsulolabral soft tissue may be higher on an ellipsoid glenoid and it may be easier to conclude with a Bankart lesion. In this context, Peltz et al. ${ }^{4}$ compared the glenohumeral joint morphology of 11 patients with anterior shoulder instability with those of uninjured volunteers and found a larger height index. However their primary result was to evaluate the radius of curvature and showed a flatter glenoid to be associated with traumatic anterior dislocation. However, it should also be noted that the study might have been statistically underpowered due to a small number of patients $(n=22)$. Similarly Owens et al. ${ }^{8}$ reported that the tall and thin glenoids were at higher risk compared with short and wide glenoids, based on the data of 39 patients with anterior instability. As is seen, similar studies have focused on risk factors of instability. Additionally, as the number of dislocations increases, the incidence of Bankart lesion is expected to increase ${ }^{6,20}$. On the other hand, Sugaya et al. ${ }^{21}$ evaluated glenoid rim morphology in patients with anterior glenohumeral instability, and found that $40 \%$ of the cases did not have an osseous fragment but demonstrated loss of the circular configuration on the en face view and obtuse contour on the oblique view, suggesting erosion or compression of the glenoid rim. Haas et al. ${ }^{22}$ evaluated instability, and arthropathy changes in patients with unilateral shoulder based on computed tomography findings and found that the average glenoid retroversion, glenoid depth, glenoid diameter and the bony shoulder stability ratio of the affected shoulder were significantly reduced compared with the contralateral 
side. They concluded that instability arthropathy is associated with morphologic parameters of the glenoid. Similarly Moroder et al. ${ }^{23}$ evaluated computed tomography images of the shoulders for differences in glenoid morphology and concluded that anterior shoulder instability is associated with an inherent flattening of the bony glenoid concavity which significantly decreases the bony shoulder stability ratio. Such studies are implicitly compatible with our results and they support our findings that glenoid bone morphology is associated with labral tears.

In the current study, the use of MR images in glenoid measurements may be a disadvantage. If the relevant measurements were made with computed tomography, it would be possible to make more precise evaluations. Nevertheless, the fact that all the measurements were made with the same program partly eliminates such disadvantage. Given that not all of the labral tears may be detected by MRI, it should be kept in mind that the obtained data are mainly based on the sensitivity of MRI. In this regard, it is of course possible to obtain clearer data by performing a similar study with higher magnet strength or arthroscopic findings.

In conclusion, our results demonstrate an association between glenoid dimensions and the occurrence of Bankart lesions: An increase in the SI diameter and SI/AP and SI/DD diameter ratio, increases the incidence of Bankart lesions.

\section{REFERENCES}

1. Dumont GD, Russell RD, Robertson WJ. Anterior shoulder instability: a review of pathoanatomy, diagnosis and treatment. Curr Rev Musculoskelet Med. 2011;4:200-7. [CrossRef]

2. Bigliani LU, Pollock RG, Soslowsky LJ, Flatow EL, Pawluk RJ, Mow VC. Tensile properties of the inferior glenohumeral ligament. J Orthop Res. 1992;10:187-97. [CrossRef]

3. Owens BD, Campbell SE, Cameron KL. Risk factors for anterior glenohumeral instability. Am J Sports Med. 2014;42:2591-6. [CrossRef]

4. Peltz CD, Zauel R, Ramo N, Mehran N, Moutzouros V, Bey MJ. Differences in glenohumeral joint morphology between patients with anterior shoulder instability and healthy, uninjured volunteers. J Shoulder Elbow Surg.
2015;24:1014-20. [CrossRef]

5. Gaskill TR, Taylor DC, Millett PJ. Management of multidirectional instability of the shoulder. J Am Acad Orthop Surg. 2011;19:758-67. [CrossRef]

6. Lippitt SB, Vanderhooft JE, Harris SL, Sidles JA, Harryman DT, Matsen FA. Glenohumeral stability from concavitycompression: A quantitative analysis. J Shoulder Elbow Surg. 1993;2:27-35. [CrossRef]

7. McPherson EJ, Friedman RJ, An YH, Chokesi R, Dooley RL. Anthropometric study of normal glenohumeral relationships. J Shoulder Elbow Surg. 1997;6:105-12. [CrossRef]

8. Owens BD, Nelson BJ, Duffey ML, Mountcastle SB, Taylor DC, Cameron KL, et al. Pathoanatomy of first-time, traumatic, anterior glenohumeral subluxation events. J Bone Joint Surg Am. 2010;92:1605-11. [CrossRef]

9. Bankart AS. Recurrent or habitual dislocation of the shoulder-joint. Br Med J. 1923;2:1132-3. [CrossRef]

10. Cetik O, Uslu M, Ozsar BK. The relationship between HillSachs lesion and recurrent anterior shoulder dislocation. Acta Orthop Belg. 2007;73:175-8.

11. Kazel MD, Sekiya JK, Greene JA, Bruker CT. Percutaneous correction (humeroplasty) of humeral head defects (HillSachs) associated with anterior shoulder instability: a cadaveric study. Arthroscopy. 2005;21:1473-8. [CrossRef]

12. DePalma AF, Cooke AJ, Prabhakar M. The role of the subscapularis in recurrent anterior dislocations of the shoulder. Clin Orthop. 1967;54:35-49. [CrossRef]

13. Jens J. The role of the subcapsularis muscle in the stability of the shoulder joint, and the Magnuson operation. Med J Austr. 1950;1:468-71.

14. Horst K, Von Harten R, Weber C, et al. Assessment of coincidence and defect sizes in Bankart and Hill-Sachs lesions after anterior shoulder dislocation: a radiological study. Br J Radiol. 2014;87:20130673. [CrossRef]

15. Baker CL, Uribe JW, Whitman C. Arthroscopic evaluation of acute initial anterior shoulder dislocations. Am J Sports Med. 1990;18:25-8. [CrossRef]

16. Reeves B. Experiments on the tensile strength of the anterior capsular structures of the shoulder in man. J Bone Joint Surg. 1968;50:858-65. [CrossRef]

17. Ribbans WJ, Mitchell R, Taylor GJ. Computerisedarthrotomography of primary anterior dislocation of the shoulder. J Bone Joint Surg. 1990;72:181-5. [CrossRef]

18. Milano G, Grasso A, Russo A, Magarelli N, Santagada DA, Deriu L, et al. Analysis of risk factors for glenoid bone defect in anterior shoulder instability. Am J Sports Med. 2011;39:1870-6. [CrossRef]

19. Speer KP, Deng X, Borrero S, Torzilli PA, Altchek DA, Warren RF. Biomechanical evaluation of a simulated Bankart lesion. J Bone Joint Surg Am. 1994;76:1819-26. [CrossRef]

20. Mishra A, Sharma P, Chaudhary D. Analysis of the functional results of arthroscopic Bankart repair in posttraumatic recurrent anterior dislocations of shoulder. Indian J Orthop. 2012;46:668-74. [CrossRef]

21. Sugaya H, Moriishi J, Dohi M, Kon Y, Tsuchiya A. Glenoid rim morphology in recurrent anterior glenohumeral instability. J Bone Joint Surg Am. 2003;85:878-84. [CrossRef]

22. Haas M, Plachel F, Wierer G, et al. Glenoid morphology is associated with the development of instability arthropathy. J Shoulder Elbow Surg. 2019;28:893-9. [CrossRef]

23. Moroder P, Ernstbrunner L, Pomwenger W, et al. Anterior Shoulder Instability Is Associated With an Underlying Deficiency of the Bony Glenoid Concavity. Am J Sports Med. 2016;44:1131-6. 